\title{
The Effectiveness of Corporate Governance and Customer Relationship Management on Moderating the Relationship between Credit Risk Management and Commercial Banks Performance in Jordan
}

Tamer Hussain Ahmed AlQudah ${ }^{1 *}$, Professor Dr. Ahmad Shukri bin Yazid ${ }^{2}$, Diaa Khalaf Ahmed AlQatawneh ${ }^{3}$, Sameer A .A. AlZoughool ${ }^{4}$

${ }^{1,3,4}$ Phd Students, UniSZA University, Kuala Terengganu, Malaysia

${ }^{2}$ Lectrure, UniSZA University, Kuala Terengganu, Malaysia

DOI: $10.36347 /$ sjebm.2020.v07i01.009

| Received: 15.01.2020 | Accepted: 23.01.2020 | Published: 29.01.2020

*Corresponding author: Tamer Hussain Ahmed AlQudah

Abstract

Review Article

The present article empirically discusses the Credit Risk Management and its impact on the overall performance of commercial banks in Jordan. Additionally, the study uses the moderating impact of Corporate Governance(CG) and Customer Relationship Management(CRM) in examining the extent of the influence of the credit risk on the banks overall productivity. The empirical studies show that there is a significant impact of CG and CRM on evaluating the credit worthiness of the customers and reduce the default rates of bank customers. In Jordan, the banks have crucial role in determining the economic strength, therefore, the banks are provided with Corporate Governance guidelines by the Central Bank of Jordan that provide them essential laws and regulations to strengthen their CRM and CG mechanism and reduce the risk related to credit, thus their overall performance is improved

Keywords: Credit Risk, commercial banks economic, Central Bank of Jordan.

Copyright @ 2020: This is an open-access article distributed under the terms of the Creative Commons Attribution license which permits unrestricted use, distribution, and reproduction in any medium for non-commercial use (NonCommercial, or CC-BY-NC) provided the original author and source are credited.

\section{INTRODUCTION}

Commercial banks in Jordan have key role in determining the competitive financial sector that seek to offer financial services to customers and manage various types of risk at the same time. It is mentioned by Marn \& Romuald [1] that credit is the cornerstone of the commercial banking sector because it strongly influences the overall stability and profitability of banks. In this aspect, loan decision is crucial because by using effective approach, they can mitigate the risk of credit related to each customer and enhance the overall performance of the banks. In Jordan, despite in the past few years, increase in competition is observed in the banking sector, yet, for evaluating loan decision they use subjective approach [2]. The author states that their evaluation is based on the certain scoring models or even the officer can use their intuition to assess the credit worth of each applicant. However, it is also crucial for the banks to determine the difference between the good and bad credit risk while evaluating the applicant attributes for the provision of loan. It means that if the banks do not provide the good loan, it may decrease the future profitability potential of the bank; on the contrary, if the banks accept bad loans, they may get into trouble and may lose not only the interest amount but principle amount too.

The highly observed credit risk in the banking sector is the risk related to the default of customers or counter party. In the initial period of 2000 , the Jordan economy reflected a substantial increase in the banking sector because it constituted a major portion of the economy, however, at the same time the banking institutions witnessed the increase in non-performing loans based of their weak evaluation mechanism [3]. This led to the financial distress in the banking sector and identified the prevalence of predatory debtors in the banking sector whose approach involved the abandonment of credit provision to the large number of customers and allowed only a few parties to avail this advantage. Nevertheless, the provision of credit is the source of generating income for the banks [4]. It is needless to say that it also involves huge risk for both, banks and customers. Those banks that have high credit risk have the increased chances of bankruptcy, yet, to reduce the number of non-performing loans, banks have to focus on their corporate governance mechanism that could limit their chance of high credit risk and 
bankruptcy. The present article is an attempt to describe the relationship between the credit risk management and its impact on the overall performance of commercial banks. Additionally, the study has selected two moderating variables, corporate governance and customer relationship management to know the extent of their impact and understand their indirect impact on the relationship between the credit risk management process and performance of the commercial banks in Jordan banking sector.

\section{Credit risk management in commercial banks in Jordan}

In the banking sector, the exposure to credit risk is the pertaining issue, globally. It is illustrated by researchers that those banks that have highest credit risk have the highest potential to adversely affect its stakeholders and lead them towards failure [5]. Particularly in the context of Jordan banking sector, this failure in banking operations is attributed to the subjective credit evaluation procedures, poor risk management, lack of attention to the applicant's characteristics and poor governance mechanism. However, the risk can be mitigated if the banks strengthen their evaluation process using strong governance mechanism and robust management practices. Credit decision is linked to the process of making decision that demonstrates if the credit must be provided to a specific customer based on their certain attributes such as income, age, social status, amount of loan, and the period to provide loan and the purpose of availing loan [6]. A major element that contributes to the decision of making credit provision is linked with the ability of borrower to pay back the amount and interest in a given period.

Credit risk is primarily described by Basel Committee of Banking Supervision [7] and is cited by Huang \& Wang [8], which stated that it is the likelihood of losing the loan amount either partially or totally due to the customers' inability to pay back the financial obligation. Credit risk is crucial in banking sector because if the bank loses even a smaller number of those customers who are the key element in the bank's success, the bank may incur huge loss. In Jordan, AlBeshtawi et al. [4] observed that the banks are significantly facing credit risk after the global financial recession in 2008-2009 because of the poor management practices who are failed to evaluate the differentiate the non-performing loans from good loans. Alhumoudi [6] claims that the failure of banks to provide the good loans is attributed to their insider lending and the high interest rates charged to borrowers in Jordan. This overall scenario increases the ratio of non-performing loans and reduces the profitability of the banks. Eling \& Marek [9] also stated that lending credit without effective decision making process increases the number of risks along with the risk of the borrower's default such as clearing risk, interest rate risk and funding risk. The historical experience states that lack of emphasis on credit portfolio is one of the reasons for the poor performance of banks. Sohilauw et al. [10] added in the literature that the inability to collect credit and the extension provided to the customers is the key contributor for financial distress in the commercial banks in Jordan.

Corporate Governance (CG) and credit risk management (CRM) in Jordan commercial banks

Recent studies conducted by Huang \& Wang

[8] and Basel Committee on Banking Supervision [11] evaluated the impact of corporate governance on the bank's overall productivity specifically those banks that have highest ratio of non-performing loans. The authors indicated that CG increases the banking ability to reach its objectives because of its positive influence on the managerial decision making process and through the improved stages of internal is described as a set of processes that are utilized by the Board of Directors and employees of the banking sector to represent the banking performance to their stakeholders (customers, dealers, government, other financial institutions and community) [12]. In Jordan banks, CG is one of the essential elements that is utilized to support the national economy and strengthens the abilities of administrative forces to deal with their concerned stakeholders. In Jordan, Central Bank of Jordan has issued the booklet for governance mechanism that helps the banks to ascertain the application of $\mathrm{CG}$ efficiently, improve its credit risk management and strengthen the overall performance.

The bank CG mechanism is a complex structure. This includes the bank's shareholders, managers, employees, BoDs. Notably, in the context of Jordan banking sector, bank executes its operations under the comprehensive rules and regulations imposed by the Central Bank of Jordan. The relation between all these factors determines how effectively banks have implemented the CG mechanism and it satisfies the needs of the stakeholders while fulfilling the rules and regulations. For investors, customers and regulators, CG mechanism of the banks play fundamental role because using this framework they can evaluate the performance of banks and evaluate the systematic risk posited due to the provision of loans.

\section{The moderating impact of Customer Relation Management (CRM) and Credit Risk (CR) in commercial banks \\ Customer Relationship Management (CRM) is} described as the set of activities that focus on the continuous relationships with their customers instead of one time individual transaction. It is further argued by researchers that if the firm has improved CRM, it will have the higher rate of customer loyalty and improved organizational performance [8]. Aebi, Sabato \& Schmid [3] noted that CRM provides various advantages to the banking sector. If the customers have the belief that if the particular bank has good customer services and 
emotional attachment with their customers, they view banks positively and can become a positive source of high performance in the market. It is worthy to mention here that customers are considered as the firm's asset because they can spread a positive word of mouth and become a source of referrals. In the context of banking sector in Jordan, customer satisfaction is related to the bank's credit worthiness and financial strength. This is highlighted by Huang \& Wang [8] in their study that CRM leads to the improved firm's performance. Ly [2] identified positive relationship between CRM, credit worthiness of the banks and their overall performance in the market.

The academic literature suggests that CRM enable banks to increase their credibility in the market by means of gaining high customer value, which is possible by fulfilling their specific needs such as their expectations related to loans and other financial assistance [3]. However, failure in CRM activities might increase the risk of various sectors in the banks, as mentioned by Al-Zamel [13]. In the context of Jordan, the researchers indicate that CRM boost their overall credibility in the market and customers feel loyalty with the bank and personalize their activities [14]. In this way, the rate of credit default can be profoundly decreased [15]. Prior studies also indicate that the efficient mechanism of CRM helps in effective flow of information between the customers and banks, which enable employees to disseminate the smooth flow of information across the bank [16]. Thus, banks maintain the robust mechanism for CRM and implement the effective decision that can benefit both the parties; banks and customers.

Banks that are committed to the effective framework of CRM, derive success for the firms' overall productivity. Research in the related area indicates that the banks that have higher credit risk are linked to their unclear objectives and commitment to CRM. Banks in Jordan have mostly implied CRM in their credit department because it gives them clear strategic direction and facilitates them to evaluate the financial strength of each applicant and reduce the overall credit risk. Those banks that are highly committed to the CRM strategy are clear in their business objectives and help them achieve overall business goals in this customer centric market.

\section{The moderating impact of Corporate Governance (CG) on credit risk management in commercial banking sector in Jordan \\ The Basel Committee on Bank Supervision} indicates that if the banks have implemented effective CG mechanism, they can achieve the public confidence and maintain the trust in their relevant stakeholders [17]. Jordan is considered as a small country whose economic progression is profoundly dependent on the transparency and effectiveness of financial institutions and banking sector. In the past events, Jordan faced financial distress such as Shamaylaeh Gate that enforced regulatory authorities to follow a sequence of legislative and financial regulations that encouraged financial institutions and banking sector to adopt robust corporate governance mechanism that could strengthen their accountability and credit worthiness in the market $[18,19]$. Moreover, to secure the stakeholders from the ineffective banking operations, $\mathrm{CG}$ defines the responsibilities of each employee in the bank and furnishes positive output in terms of improved market performance. In Jordan, CG in banking sector is still not widely implemented. However, the increasing pressure from the stakeholders about the transparency and accountability of banks, the Central Bank of Jordan have imposed certain regulations that are necessary to implement because in this way they can gain the public confidence and improve overall performance in the local and international market.

\section{CONCLUSION}

From the findings of the study, it is concluded that banks performance is directly related to the $\mathrm{CG}$ mechanism and CRM. Moreover, the focus on credit aspect by means of strengthening the bank's CG and CRM, the management can reduce the probability of credit risk. However, it is important for the managerial body to remain cautious at the time of credit decision because if it is not effectively evaluated, it may negatively influence the overall performance of the bank and eventually it leads to the economic and financial distress in the country. From the prior studies, it is clear that banking sector in Jordan play key role in determining the economic strength, therefore, the extent of CRM and CG mechanism must be considered because they are crucial at the time of deciding the credit provision.

\section{REFERENCES}

1. Marn JTK and Romuald DF. The impact of corporate governance mechanism and corporate performance: A study of listed companies in Malaysia. Journal for the advancement of science \& arts. 2012;3(1), 31-45.

2. Ly KC. Liquidity Risk, Regulation and Bank Performance: Evidence from European Banks. Global Economy and Finance Journal. 2015;8(1), 11-33.

3. Aebi V, Sabato $G$ and Schmid M. Risk management, corporate governance, and bank performance in the financial crisis. Journal of Banking \& Finance. 2012; 36(12), 32133226. doi:10.1016/j.jbankfin.2011.10.020

4. Al-Beshtawi SH, Zraqat OM and Hiyasat HMDA. The Impact of Corporate Governance on NonFinancial Performance in Jordanian Commercial Banks and Islamic Banks. International Journal of Financial Research. 2014; 5(3).

5. Krasnikov A, Jayachandran S and Kumar V. The Impact of Customer Relationship Management Implementation on Cost and Profit Efficiencies: 
Evidence from the U.S. Commercial Banking Industry. Journal of Marketing. 2009; 73(6), 6176.

6. Alhumoudi HY. Corporate Governance Mechanisms and Firms' Performance: An Empirical Analysis of Firms Listed on the Saudi Stock Exchange. International Journal of Accounting and Financial Reporting. 2016; 6(2), 101-145.

7. Basel Committee on banking Supervision. "Risk Management Practices and Regulatory Capital: Cross-sectional Comparison”. Basel Committee on Banking Supervision, www.bis.org.2001;

8. Huang YS and Wang CJ. Corporate governance and risk-taking of Chinese firms: The role of board size. International Review of Economics \& Finance.2015; 37, 96-113.

9. Eling M and Marek SD. Corporate governance and risk taking: Evidence from the UK and German insurance markets. Journal of Risk and Insurance.2014; 81(3), 653-682.

10. Sohilauw MI, Ali M, Pahlevi $\mathrm{C}$ and Nohong M. Moderation of Customer Mentoring and Relationship Management (CMRM) to the relationship between capital structure decisions with SME financial performance in Makassar City. IOP Conference Series: Earth and Environmental Science.2019; 235, 012087.

11. Basel Committee on Banking Supervision. "Studies on Credit Risk Concentration", An Overview of the Issues and a Synopsis of the Results' from the research Task Force Project. www.bis.org.2009.
12. Corporate Governance and Performance. Banking Governance, Performance and RiskTaking.2016; $143-154$.

13. Al-Zamel N. The Impact of Internal Corporate Governance Instruments on Bank's Risk of Jordanian Islamic Banks (period 2008-2013). The World Islamic Science University \& Education University (wise), Amman; 2015.

14. Dr. Khaled Abdalla Mohâ€ TMD Al- Tamimi and Obeidat SF. Determinants of Capital Adequacy in Commercial Banks of Jordan an Empirical Study. International Journal of Academic Research in Economics and Management Sciences.2013; 2(4).

15. Bessis J. Risk Management in Banking, John Willey \& Sons. Inc., New York; 2002.

16. Pietrabissa E. Management of banks' international lending: Country risk analysis and country exposure measurement and control. European journal of operational research. 1987 Jun 1;30(1):42-7.

17. Basel Committee. "International convergence of capital measurement and capital standards", Basel Committee on Banking Supervision.1998.

18. Al-Smadi MO. Examining the relationship between corporate governance and banks' performance, and risk in Saudi Arabia. European journal of economics, finance and administrative sciences.2013; 16(2), 59-62.

19. Basel Committee. "Principles for management of credit risk", Basel Committee on Banking Supervision; 1999. 